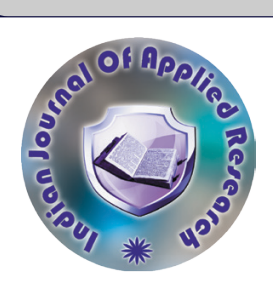

Mr. N. Ramesh

\title{
A SCIENTIFIC STUDY ON EFFECT OF YOGIC PRACTICES ON SPEED AMONG HANDBALL MEN
}

\section{Dr. G. Ravindran*}

Ph. D., Research Scholar Tamil Nadu Physical Education And Sports University, Chennai, Tamil Nadu, India

Professor Tamil Nadu Physical Education And Sports University, Chennai, Tamil Nadu, India *Corresponding Author of the study men handball players were selected from affiliated college from Tamil Nadu Physical Education and Sports University, Chennai, Tamil Nadu, India during the year 2019. The subject's age ranges from 18 to 25 years. The selected students were divided into two equal groups consists of 15 handball men each namely experimental group and control group. The experimental group underwent a yogic practices programme for six weeks. The control group was not taking part in any training during the course of the study. Speed was taken as criterion variable in this study. The selected subjects were tested on Speed was measured through 50 yards dash. Pre-test was taken before the training period and post- test was measured immediately after the six week training period. Statistical technique ' $t$ ' ratio was used to analyse the means of the pre-test and post test data of experimental group and control group. The results revealed that there was a significant difference found on the criterion variable. The difference is found due to yogic practices given to the experimental group on Speed when compared to control group.

KEYWORDS : Yogic Practices, Speed And't' Ratio.

\section{INTRODUCTION}

Today, sports have become a part and parcel of our culture. It is being influenced and does influence all our social institutions including education, economics, arts, politics, law, mass communication and even international diplomacy (Alaguraja, K. et.al, 2019). Yoga is universally benefiting all people of all ages. The study of Yoga is fascinating to those with a philosophical mind and is defined as the silencing of the mind's activities which lead to complete realization of the intrinsic nature of the Supreme Being (Alaguraja, K. et.al., 2017)1. In the sports world, physical education is the most essential aspect due to the fact physical schooling increases the performance and the effectiveness of the sports (Alaguraja, K. et.al., 2018) ${ }^{2}$.

Yoga is a system of exercises which helps the mind and body in order to achieve tranquillity and spiritual insight (Alaguraja, K. et.al, 2019) ${ }^{5}$. Make sure that when you practice yoga asanas, you don't just stretch the body because the mind has to be with the body. (Alaguraja, K. et.al, $2019)^{8}$. One can start practicing Yoga at any given moment of time and you may start with meditation or directly with pranayama without even doing the asanas (postures). (Alaguraja, K. et.al, 2019) ${ }^{3}$. Today's there is an escalating emphasis on appearing smarter, feeling etter and living longer. In order to achieve these ideals as, scientific evidence tells us that one of the keys is high fitness and exercises (Alaguraja, K. et.al, 2019) ${ }^{7}$. When consciousness is operating with the intellect and with all the senses, by making an individual think that he or she is awake and aware, but the mind is actually less receptive and more critical (Yoga, P. et. al., 2019) $)^{10}$. Yoga is a practical aid, not a religion and its techniques may be practiced by Buddhist, Jews, Christians, Muslims, Hindus and Atheist alike. Yoga is union for all (Selvakumar, K. et.al, $2019)^{9}$.

\section{RESEARCH METHODOLOGY \\ SELECTION OF SUBJECTS}

The purpose of the study was to find out the yogic practices on speed among handball men. To achieve this purpose of the study, thirty handball men were selected as subjects at random. The age of the subjects were ranged from 18 to 25 years.

\section{SELECTION OFVARIABLE \\ INDEPENDENT VARIABLE \\ - Yogic practices}

\section{DEPENDENT VARIABLE}

- Speed

\section{EXPERIMENTALDESIGN AND IMPLEMENTATION}

The selected subjects were divided into two equal groups of fifteen subjects each, such as a yogic practices group (Experimental Group) and control group. The experimental group underwent yogic practices for six days per week for six weeks. Control group, which they did not undergo any special training programme apart from their regular physical activities as per their curriculum. The following physical variable namely speed was selected as criterion variable. All the subjects of two groups were tested on selected criterion variable Speed was measured through 50 yards dash at prior to and immediately after the training programme.

\section{STATISTICAL TECHNIQUE}

The't' test was used to analysis the significant differences, if any, difference between the groups respectively.

\section{LEVEL OF SIGNIFICANCE}

The 0.05 level of confidence was fixed to test the level of significance which was considered as an appropriate.

\section{ANALYSIS OF THE DATA}

The significance of the difference among the means of the experimental group was found out by pre-test. The data were analysed and dependent't' test was used with 0.05 levels as confidence.

TABLE I Analysis of t-ratio for the pre and post tests of experimental and control group on Speed (Scores Seconds)

\begin{tabular}{|l|c|c|c|c|c|c|c|}
\hline Variables & Group & \multicolumn{2}{|c|}{ Mean } & \multicolumn{2}{c|}{ SD } & df & $\begin{array}{c}\text { 't' } \\
\text { ratio }\end{array}$ \\
\hline & & Pre & Post & Pre & Post & & \\
\hline Speed & Control & 6.39 & 6.40 & 0.191 & 0.195 & 14 & 0.65 \\
\hline & Experimental & 6.41 & 6.21 & 0.184 & 0.144 & & $\mathbf{9 . 4 8 *}$ \\
\hline
\end{tabular}

*Significance at .05 level of confidence.

The Table-I shows that the mean values of pre-test and post-test of the control group on Speed were 6.39 and 6.40 respectively. The obtained ' $t$ ' ratio was 0.65 , since the obtained ' $t$ ' ratio was less than the required table value of 2.14 for the significant at 0.05 level with 14 degrees of freedom it was found to be statistically insignificant. The mean values of pre-test and post-test of the experimental group on Speed were 6.41 and 6.21 respectively. The obtained ' $\mathrm{t}$ ' ratio was $9.48^{*}$ since the obtained ' $t$ ' ratio was greater than the required table value of 2.14 for significance at 0.05 level with 14 degrees of freedom it was found to be statistically significant. The result of the study showed that there was a significant difference between control group and experimental group in Systolic blood pressure. It may be concluded from the result of the study that experimental group improved in Speed due to six weeks of yogic practices. 
Figure-1 Bar Diagram Showing the Pre and Post Mean Values of

Experimental and Control Group on Speed

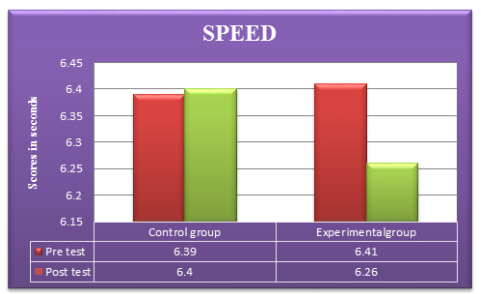

\section{DISCUSSIONS ON FINDINGS}

The result of the study indicates that the experimental group, namely yogic practices group had significantly improved the selected dependent variable, namely speed, when compared to the control group. It is also found that the improvement caused by yogic practices when compared to the control group.

\section{CONCLUSION}

On the basis of the results obtained the following conclusions are drawn,

1. There was a significant difference between experimental and control group on Speed after the training period.

2. There was a significant improvement in speed. However the improvement was in favor of experimental group due to six weeks of yogic practices.

\section{REFERENCES}

1. Alaguraja, K., \& Yoga, P. (2017). Influence of yogasana practice on flexibility among obese adolescent school boys. International Journal of Yoga, Physiotherapy and Physical Education, 2(7), 70-71

2. Alaguraja, K., \& Yoga, P. (2018). Effect of core stability training on dynamic strength among college male students. International Journal of Yogic, Human Movement and Sports Sciences, 3 (2), 436-437.

3. Alaguraja, K., \& Yoga, P. (2019). Effect of yogic practice on resting pulse rate among school students. Indian Journal of Applied Research, $9,(7), 17-18$

4. Alaguraja, K., Yoga, P., Balamuralikrishnan, R., \& Selvakumar, K. (2019). A scientific study on efficacy of yogic package on resting pulse rate among obese school students. Journal of Information and Computational Science, 9(8), 483-487.

5. Alaguraja, K., \& Yoga, P. (2019). Effect of yogic practice on resting pulse rate among school students. Indian Journal of Applied Research, 9, (7), 17-18.

6. Alaguraja, K., \& Yoga, P. (2019). Analyze of pranayama technique on physiological parameter among rural school students. Journal of Information and Computational Science, $9(8), 545-550$.

7. Alaguraja, K., Yoga, P., James Rathinaraj, S., R., \& Selvakumar, K. (2019). A study on yoga intervention on maximal oxygen uptake among stress patient. Indian Journal of yoga intervention on maximal oxygen uptake among stress patient. Indian Journal of

8. Alaguraja, K., \& Yoga, P. (2019). Effect of yogic practice on resting pulse rate among school students. Indian Journal of Applied Research, 9, (7), 43-44.

9. Selvakumar, K., \& Yoga, P. (2019). Influence of yogic practice on flexibility among college students. Indian Journal of Applied Research, 9, (7), 45-46.

10. Yoga, P., Balamuralikrishnan, R., \& Alaguraja, K. (2019). Influence of cyclic meditation on selected physiological parameter. International Journal of Advanced Education and Research, 4(1), 17-18.

11. Jackson C. Healing ourselves, healing others: first in a series. Holistic Nursing Practice, 2004; 18(2): p. 67-81.

12. Strukic, P.J. Basic Physiology, New York: Spring Ervellong Inc. 1981; p.23.

13. Farhi D.,(2005). Bringing Yoga to Life: The everyday practice of Enlightened Living. Harper Collins Publisher, Australia.

14. Sunil(2014). The importance of yoga in daily Life. https:/ www. Researchgate.net/publication/278673574, accessed. 2015, 2017. 